\title{
A new species of Ramaria subg. Ramaria from western North America
}

\author{
RONALD H. PETERSEN and CATHERINE SCATES
}

\begin{abstract}
PETERSEN, R.H. \& SCATES, C. 2000: A new species of Ramaria subg. Ramaria from western North America. - Karstenia 40: 139-142. Helsinki. ISSN 0453-3402.

Ramaria subviolacea R.H. Petersen \& C. Scates is proposed as a new species of Ramaria subg. Ramaria. The species fruits in moist forests under Abies grandis in northern Idaho and western Washington in the United States. Ramaria strasseri basidiomata are similar, and a lectoype specimen for that species designated.
\end{abstract}

Key words: new species, Ramaria, taxonomy

Ronald H. Petersen, Botany Department, University of Tennessee, Knoxville, TN 37996-1100, USA.

Catherine Scates, E 2830 Marine Dr., Post Falls, Idaho 83854, USA.

\section{Introduction}

Of the subgenera of Ramaria, subg. Ramaria appears to include fewest species. These species, however, comprise two general complexes, and both complexes present difficult taxonomic problems. One complex [i.e. R. botrytis (Fr.) Ricken; $R$. holorubella (Atk.) Corner, etc.] is characterized by red to wine-colored branch apices and/ or rufescent bruising or staining of stipe and lower branches. The other complex comprises taxa [i.e. R. strasseri (Bres.) Corner, 1950; R. daucipes Petersen, etc.] with buffy avellaneous branch apices when young, and generally massive stipes, but no distinct red or ruby coloration.

For some years, one of us (CS) has collected specimens of Ramaria belonging to the latter complex but apparently undescribed. Marr and Stuntz (1973) used the name R. strasseri for such specimens, but their taxon included at least two basidiome statures, neither one conforming to Bresadola's specimens of $R$. strasseri. In order to work on these Scates collections, it was necessary not only to examine those collections, but also to examine similar material collected by Marr and authentic specimens of $R$. strasseri. These items are taken up below.

\section{Materials and methods}

Specimens cited below were collected by CS. Micromorphological observations and comparison with other material were performed by the senior author (RHP). Spore ornamentation was viewed under bright field microscopy using lactic acid-cotton blue. Recipes for macrochemicals were taken from Marr and Stuntz (1973). In citing basidiospore dimensions, $\mathrm{n}=$ number of spores measured/number of collections examined.

Ramaria subviolacea R.H. Petersen \& C. Scates, sp. nova - Figs. 1-3

Species in subg. Ramaria. Rami cremea; ramuli subviolacea. Stipes contextus albus, solidus, amyloideus. Basidiosporae 12-19 × 5-7 $\mu \mathrm{m}$, striatulatae, cyanophilae. Dist. America septentrionali-occidentalis, in Idaho septentrionali crescentii, sub Abies et Pseudotsuga.

Holotypus: U.S.A. Idaho, Kootenai Co., vic. Hayden Lake, Rimrock Rd., 4.XI.1977 C. Scates KS4792 (TENN 58326).

Basidiomata broadly clavate to broadly spheropedunculate in profile. Stipe $60-100 \times 50-80$ $\mu \mathrm{m}$, single, often accounting for more than half of basidiome height, off-white, usually faintly lined, naked or with few shallowly pyramidal scale-like 


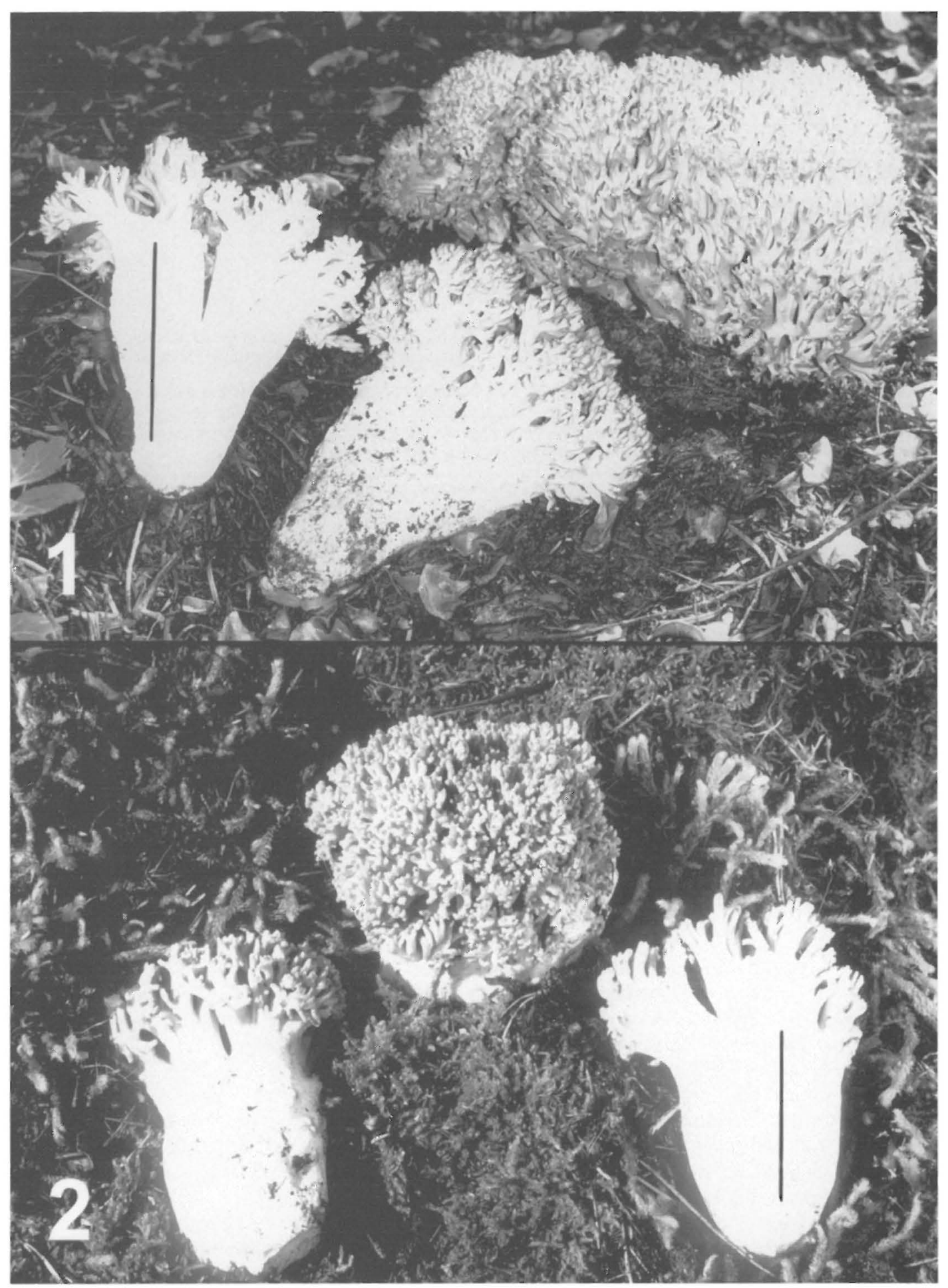

Fig. 1, 2. Basidiomata of Ramaria subviolacea . Bar $=5 \mathrm{~cm}$. 
primordial branchlets; flesh solid, white, fleshyfibrous, often with insect channels, quickly and distinctly amyloid. Branches numerous, $8-16 \mathrm{~mm}$ long, sudivaricate, muscled to shallowly channeled, off-white to yellowish gray; axils rounded to lunate. Apices pluridentate to dentate, knobby to obtusely rounded at maturity, when young 7C3-8B2 ("vinaceous drab" to "ecru drab"; 6YR $6.6 / 2.0$ ), mellowing (through spore accumulation?) to yellowish gray. Taste mild; odor faintly musty. Cut stipe flesh quickly amyloid in IKI, branch sections without significant change in pyrogallol, a-napthol, guaiac, guaiacol, phenol, and aniline oil.

Stipe trama monomitic; generative hyphae 4.5-10(-20) $\mu \mathrm{m}$ diam, tightly interwoven, occasionally inflated, rarely thin- to thick-walled (wall up to $1.2 \mu \mathrm{m}$ thick), hyaline singly, somewhat refringent under phase contrast optics, clamped; clamp connections variable in shape, including alliiform, up to $15 \mu \mathrm{m}$ thick), sparsely ornamented. Hyphae of upper branch flesh 2.5-7.5 $\mu \mathrm{m}$ diam, hyaline, thin-walled, strictly parallel, not adherent, clamped; clamp connections occasionally alliiform and then thick-walled (wall up to 0.8 $\mu \mathrm{m}$ thick), unornamented. Subhymenium rudimentary, up to $30 \mu \mathrm{m}$ thick; hyphae $2.5-4.0 \mu \mathrm{m}$ diam, hyaline, tightly interwoven, frequently clamped, not adherent. Hymenium thickening to at least $100 \mu \mathrm{m}$; basidia 55-64 × 8.5-10 $\mu \mathrm{m}$, clavate, hyaline, clamped; contents apparently homogeneous; sterigmata four, curved, up to $6.5 \mu \mathrm{m}$ long. Basidiospores (Fig. 3; $\mathrm{n}=84 / 4$ ) $12.0-18.0$ $(-19.2) \times 5.0-7.0(-7.6) \mu \mathrm{m}(\mathrm{E}=1.71-2.87 ; \mathrm{Em}=2.39$; $\mathrm{Lm}=14.13 \mu \mathrm{m})$, ellipsoid, roughened in outline, longitudinally to obliquely striate (in aniline blue), thick-walled (wall up to $0.4 \mu \mathrm{m}$ thick); contents obscurely 2-multiguttulate: hilar appendix blunt, not prominent.

Habitat: deeply buried in needle debris and humus under Abies grandis and Pseudotsuga menziesii; northern Idaho and western Washington.

Additional specimens examined: R. strasseri: Austria. Lower Austria, Sonntagberg, IX.1899, herb. Bresadola (lectotype; S, NCU!); same location, no date, misit Bresadola, herb. Lloyd (Lloyd no. 34454; BPI). R. subviolacea: Idaho, Kootenai Co., vic. Hayden lake, Rimrock Rd., 5.X.1978 C. Scates KS5251 (TENN 58328); Kootenai Co., Panhandle National Forest, Cherry Creek, East Hayden Lake Rd., 3.X.1989 C. Scates KS7316 (TENN 58329); same location, 11.X.1977 C. Scates KS4716 (TENN 58327). Washington, Lewis Co., vic. Elba, Pleasant Valley, 8.XI.1966 Marr 534, as R. strasseri (SUCO).

\section{Discussion}

Within subg. Ramaria there is a complex of taxa exhibiting similar basidiomata; all with buffy violaceous or avellaneous branch apices, and all with massive stipes. The European material is $R$. strasseri, which shares branch apex color (Bresadola: "ramis avellaneo cinnamomeo-umbrinis; ...ramulis ... concoloribus..."), general spore ornamentation and measurements (two Bresadola specimens, see below, : 13.3-17.4 × 5.0-6.6. $\mu \mathrm{m}$; $\mathrm{E}=2.22-3.00 ; \mathrm{Em}=2.63)$, but according to Bresadola's plate (1932, pl. MLXXXIX) differs substantially in branch shape and elongation (branches depicted being as long as the stipe is high). Amyloidity of stipe flesh, of course, was not noted and is now unreliable in authentic specimens.

Clavaria strasseri Bresadola was described in Strasser's Pilzflora Sonntagsberg (1900: vol. 2 , p. 3) based on a specimen contributed by Strasser. Bresadola's herbarium is housed chiefly at Stockholm (S), and a specimen there labelled as " $C$. strasseri Bres. n. sp." was divided and a portion sent to W.C. Coker at University of North Carolina. Coker accepted the specimen (annotation in NCU) portion as the type of the species.
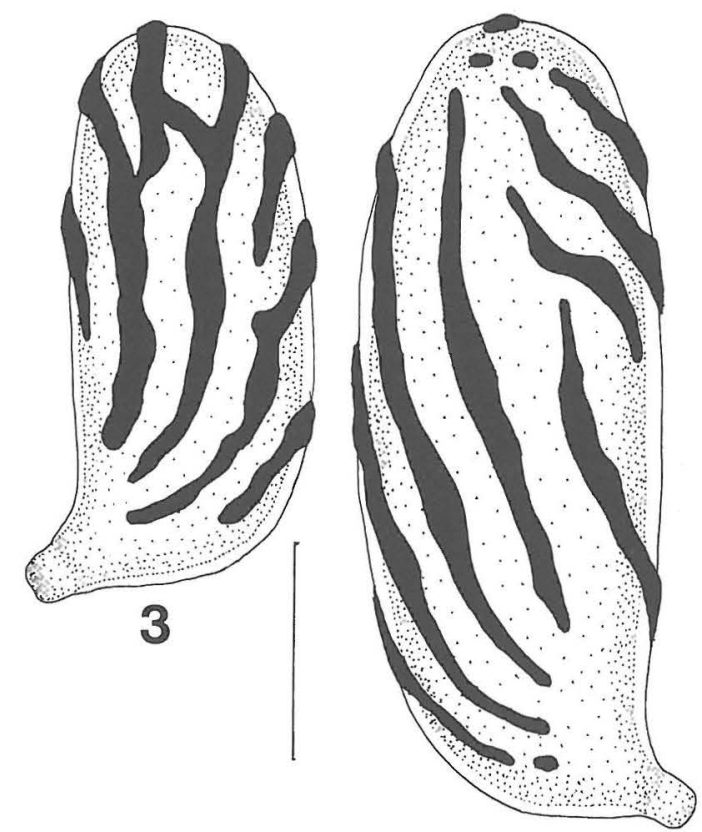

Fig.3. Basidiospores of Ramaria subviolacea. Bar $=5$ $\mu \mathrm{m}$. 
The designation was not published, however. Consequently, the Stockholm (S) specimen ["Sonntagsberg. (Austria) Sep. 1899" herb. Bresadola] is here designated as lectotype of $\mathrm{Cl}$ avaria strasseri [isolectotype, NCU].

It would appear that Ramaria subviolacea is the same as at least some of the specimens cited by Marr ands Stuntz (1973: 46-47) under $R$. strasseri. Marr (pers. comm.) knew that the name was doubtful, but knew no other appropriate epithet. The photo by Marr and Stuntz (1973: fig. 65 ) of Marr 444 shows a very different basidioma with smaller stipe beset with numerous primordial branchlets, but a photo (and specimen) of Marr 534 shows a large, virtually naked, obconical, pale stipe and bushy branches and apices. The description furnished (presumably including both basidiome structures) mentions amyloid stipe flesh and my measurements of the basidiospores of Marr $534(12.2-15.5 \times 5.0-6.1 \mu \mathrm{m}$; $\mathrm{E}=2.27-2.8 ; \mathrm{Em}=2.57 ; \mathrm{Lm}=13.98 \mu \mathrm{m})$ compares favorably with those of $R$. subviolacea.

\section{References}

Bresadola, J. 1932: Iconographia Mycologica 22. - Soc. Bot. Italiana Mus. Civ. Stor. Nat. Trento.

Coker, W.C. 1923: The clavarias of the Unites States and Canada. - Univ. North Carolina Press, Chapel Hill. 209 pp.

Corner, E.J.H. 1950: A monograph of Clavaria and allied genera. - Ann. Bot. Mem. 1:740.

Marr, C.D. \& Stuntz, D.E. 1973: Ramaria of western Washington. - Biblioth. Mycol. 38:1-232.

Strasser, P.P. 1900: Pilzflora des Sonntagberges (N.-Ö.) - Beiträge zur Pilzflora Nieder-Österreichs I. - Verh. Zool.-bot. Ges. Wien 50:293-331. 